\title{
Quantitative Assessment of Land Cover Change Using Landsat Time Series Data: Case of Chunati Wildlife Sanctuary (CWS), Bangladesh
}

\author{
Kamrul Islam*1, Mohammed Jasimuddin ${ }^{1}$, Biswajit Nath ${ }^{2}$, Tapan Kumar Nath ${ }^{1,3}$ \\ ${ }^{1}$ University of Chittagong, Institute of Forestry and Environmental Sciences, CHITTAGONG-BD \\ ${ }^{2}$ University of Chittagong, Department of Geography and Environmental Studies, CHITTAGONG-BD \\ ${ }^{3}$ University of Nottingham Malaysia Campus, School of Biosciences, SEMENYIH-MY
}

Corresponding author* Tel: +08801836763416

E-mail: ksujonifescu@gmail.com

Received 13 April 2016

Accepted 27 June 2016

\begin{abstract}
Due to inappropriate management and absence of land use planning, land cover change of developing country like Bangladesh is a common phenomenon. This land cover change phenomenon will have its tremendous effect if found at a greater extent on natural habitat area for numerous animal and tree species. In this study, land cover change of Chunati Wildlife Sanctuary (CWS) was assessed from (2005-2015) using Landsat TM (Thematic Mapper) and Landsat 8 OLI/TIRS (Operational Land Imager/Thermal Infrared Sensor). ArcGIS v10.1 and ERDAS Imagine v14 were used to process satellite derived imageries and assess other quantitative data for land cover change assessment of this study area. Land cover change of the area was identified using Normalized Difference Vegetation Index (NDVI) technique. Highest NDVI value was found in 2005 (0.71) which denotes presence of moderate-high vegetation cover at that time period. After 2005, highest NDVI value was found following a decreasing trend (0.56 in 2010 and 0.4 in 2015) which clearly represents the rapid vegetation cover change in the study area. Almost 7608 hectares of moderate to high density natural forest cover dominated the area during 2005 but was totally absent in 2015 which may be considered as a great threat regarding proper ecosystem functioning of CWS. From the findings of this research, it can be easily concluded that the sanctuary area has lost its valuable land cover both qualitatively and quantitatively.
\end{abstract}

Keywords: Land Cover Change, Remote Sensing, NDVI, Chunati Wildlife Sanctuary, Landsat Satellite Imagery

\section{Introduction}

The physical entity in terms of topography, spatial nature which is associated with economic value is land (FAO, 1995). Land use/land cover change (LULCC) or simply land change is the term for the modification of earth's terrestrial surface by human being (Ellis, 2013) and it is so pervasive that if aggregated globally can significantly affect the earth's system proper functioning (Lambin et al., 2001). Land use is defined as series of operations on land by humans whether land cover is commonly the vegetation cover both natural and planted, building constructions, and water bodies that cover the earth surface of the earth (Coffey, 2013). Alterations in land cover affect the sustainability of ecosystem (Vescovi et al., 2002) and human actions most of the cases accelerate the process (Agarwal et al., 2001). Though land cover change is sometimes natural phenomenon but the vast growing population of the world is contributing enough for further change of it (López et al., 2001) considering the bio-physical and socio-economic attributes of regions (Aspinall, 2004; Zeng et al., 2008). The reasons behind natural land cover changes are many ( Veldkamp, 1997; Agarwal et al., 2001; Geist, 2005; Lambin, 1997; Veldkamp \& Lambin, 2001; Zeng et al., 2008); but amongst them tropical deforestation, rangeland modification, agricultural intensification, urbanization and globalization are the prime causes and factors for global, regional land use/land cover changes (Lambin et al., 2001).

In order to prevent forest degradation and to protect the wildlife, mainly of Asian elephant, Chunati reserve forest was declared as the Chunati Wildlife Sanctuary (CWS) in 1986 which represents a fragile forest landscape near the Bay of Bengal. If the sanctuary is not 
conserved soon, may be lost for the future generation which is a matter of serious concern considering the value of this unique ecosystem. Anthropogenic pressures such as increased commercial extraction of forest produce, brought by manifold increase in human population that ultimately led to widespread shrinkage and deforestation of hill forests which in turn ultimately converts the natural land cover into different land uses. Conversion of land cover into human induced land uses have tremendous effect on the natural habitats of plant and animal species of this area which is a threat for the sustaining of this fragile ecosystem (NSP, 2004). Change in land cover due to due to human induced activities or others may have a tremendous effect on the surrounding environment. In order to take proper steps considering this, top most priority is given on the information relating to the quantitative assessment of change from a base time period. Remote sensing can be a great tool in this aspect as used worldwide due to its cost-effectiveness.

Change detection is the temporal effects as variation in spectral response which involves situations where the spectral characteristics of the vegetation or other types of cover in a location change over time (Hoffer, 1978). Singh (1989) described this technique as a process which observes the differences of phenomenon or objects at different times. A number of techniques is available for studying the seasonal changes in vegetation using satellite imageries, among them vegetation indices quantify the range of greenness (Chuvieco, 1998). Change in vegetation can be evaluated using the vegetation indices. One of the prominent and widely used such indices is Normalized Difference Vegetation Index (NDVI) which measures balance between energy received and energy emitted by objects on earth. When this thing is applied on plant community, the index establishes a value range to represent the greenness of that particular area and this is the indirect quantification of vigor of growth of plants (Tovar, 2012). NDVI approach is based on the fact that dense or healthy vegetation has a low acceptance in the visible portion of electromagnetic spectrum due to chlorophyll absorption and high acceptance in the near infrared band because of the internal reflectance from the mesophyll tissue of green leaf of plants.
This is also the reason behind the use of red and near infrared band of images while NDVI processing (Campbell, 1987). The range of NDVI value is from -1 to +1 ; due to the reason of high acceptance in the near infrared portion of electromagnetic spectrum, dense or healthy vegetation is represented by high value between 0.1 and 1 . Reverse to this, water bodies, bare rock etc. land cover or commonly non-vegetated surfaces yield negative to close to zero values of NDVI because the absorption of electromagnetic spectrum (Lillesand and Kiefer, 1979, 1994 and 2000).

This paper discusses the change in land cover of the CWS from 2005 - 2015 using Landsat time series data (i.e. 2005, 2010, and 2015). While reviewing literature it is found that massive destruction of forest was done during this period of time so that this time period is considered for the study. The overall objectives of this piece of research is to assess and quantify the change in vegetation cover of CWS within this 15 years of study period.

\section{Materials and Methods}

\section{Background Information of the Study Area}

The CWS is a tropical semi-evergreen forest in Bangladesh, situated at about $70 \mathrm{~km}$ south of Chittagong city on the west side of Chittagong Cox's Bazar Highway. The area lies between $21^{\circ} 40^{\prime} \mathrm{N}$ 92 $2^{\circ} 07^{\prime} \mathrm{E}$ (Figure 1). Different literature shows that he Wildlife Sanctuary covers an area of 7763.94 ha. But in this piece of research the area considered for CWS is 10822.77 hectares. This 3058.83 ha or $39.37 \%$ area increased due to the reason that there were irregularities in the map boundaries which is very difficult to maintain in this present map; another important thing is that still there are some privately acquired land inside the sanctuary area which is also included in this map thus increased the overall area of the CWS area. Removal of this area will certainly decrease the present area that is used in this study, but due to the difficulties it can't be done in this study. Regarding all these issues, the Area of Interest (AOI) for CWS is considered 10822.77 hectares. The sanctuary embraces partly 7 unions (namely Chunuti, Adhunagar, Harbang, Puichari, Banskhali, Borohatia, Toitong) of 
Banskhali and LohagaraUpazila of Chittagong District and ChokoriaUpazila of Cox's Bazar District. Chunati WS was formally established through a Gazette Notification in 1986 under the provision of Wildlife preservation Act. There are 7 mouzas, divided into 15 villages and further divided into about 70 settlements (locally called para). Of the paras, about $48 \%$ is located inside and at the edge of the forest and the rest are located outside, but adjacent and nearby the forest.

\section{Location of Chunati Wildlife Sanctuary(CWS), Bangladesh}

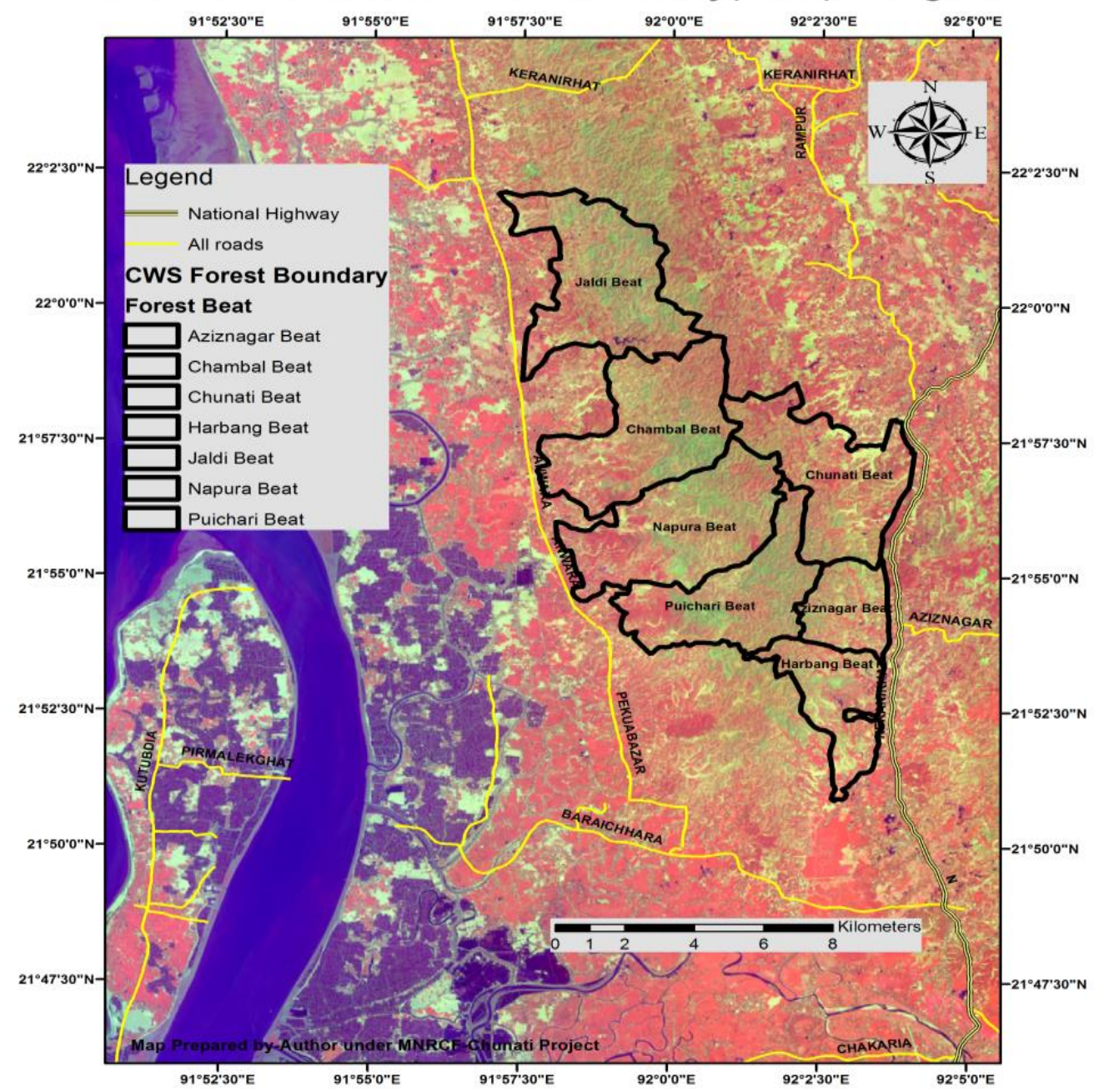

Figure 1: Location Map of the Study Area

\section{Data Used:}

Base map of the study area was prepared using satellite imageries from Google Earth 7.0v. Printed subset images from Google Earth were combined manually and used to recognize different features in the study area. The latest high resolution satellite imagery provided by Google Earth and NASA-GLCF Global Land Cover Facility Archive (freely downloadable worldwide) for Landsat TM and USGS for Landsat 8 OLI-TIRS satellite imagery (2005-2015) were used for visual image interpretation, land use identification and land use classification (Figure 2). All of these 
Landsat TM and Landsat 8 OLI-TIRS sensors have spatial resolution of $30 \mathrm{~m}$. Characteristics of Landsat data are shown in Table 1.

\section{Methodology}

Landsat TM and Landsat 8 OLI-TIRS data were used in this study. Normalized Difference Vegetation Index (NDVI) and Land use change assessment of the study area were performed from the satellite imageries using ArcGIS 10.1 \& ERDAS Imagine 14. Both ArcGIS 10.1 \& ERDAS Imagine 14 were used for image processing, classification, its final analysis, NDVI and Land use map generation respectively to achieve the objectives of the study. Excel spreadsheet 2010 was also used for analyzing the results.

Table 1: Data Characteristics of Satellite Imageries (Source: NASA-Global Land Cover Facility (GLCF) and USGS Landsat 8 OLI-TIRS Series Archive)

\begin{tabular}{ccccc}
\hline Satellite & Sensor & $\begin{array}{c}\text { Band } \\
\text { Combinations }\end{array}$ & Date of Acquisition & $\begin{array}{c}\text { Spatial } \\
\text { Resolution }\end{array}$ \\
\hline Landsat & TM & NIR, R, G (4,3,2) & 25 November 2005 & $30 \mathrm{~m}$ \\
Landsat & TM & NIR, R, G (4,3,2) & 08 February 2010 & $30 \mathrm{~m}$ \\
Landsat 8 & OLI-TIRS & NIR, R, G (5,4,3) & 26 March 2015 & $30 \mathrm{~m}$ \\
\hline
\end{tabular}

ERDAS Imagine was used to generate the false color composite, by combining near infrared, red and green which were bands $4,3,2$ together for the two (2) imageries of 2005, $2010 \& 5,4,3$ band combinations of Landsat 8/OLI TIRS Image of 2015. This false color composite was used for vegetation recognition; its range wise index classification, because chlorophyll in plants reflects very well in the near infrared rather than visible band. Then three individual NDVI maps (2005-2015) were prepared. The use of the Normalized Difference Vegetation Index (NDVI) was applied to detect areas of vegetation cover change of Chunati Wildlife Sanctuary (CWS) and different year wise NDVI derived quantitative data were generated and summarized using remote sensing and GIS software. The method which was followed for this present research is shown in the following flow chart model (Figure 2.2). NDVI from reflectance images is obtained by mean of channels $3(0.63-0.69 \mu \mathrm{m})$ and 4 (0.78-0.90 $\mu \mathrm{m})$ for Landsat TM Data and for Landsat 8 OLI-TIRS Imagery channel 4 (0.64-0.67) and 5 (0.85-0.88). The formula for NDVI calculation for Landsat TM of 2005 and 2010 is shown in equation 1 and for Landsat 8 OLI-TIRS of 2015 respectively are shown in equation 2 .

$$
\begin{gathered}
\text { NDVI }=\frac{\text { Band } 4-\text { Band } 3}{\text { Band } 4+\text { Band } 3} \ldots \ldots \ldots \ldots . .(\text { Eq. } 1) \\
\text { NDVI }=\frac{\text { Band } 5-\text { Band } 4}{\text { Band } 5+\text { Band } 4} \ldots \ldots \ldots \ldots \ldots(\text { Eq. } 2)
\end{gathered}
$$




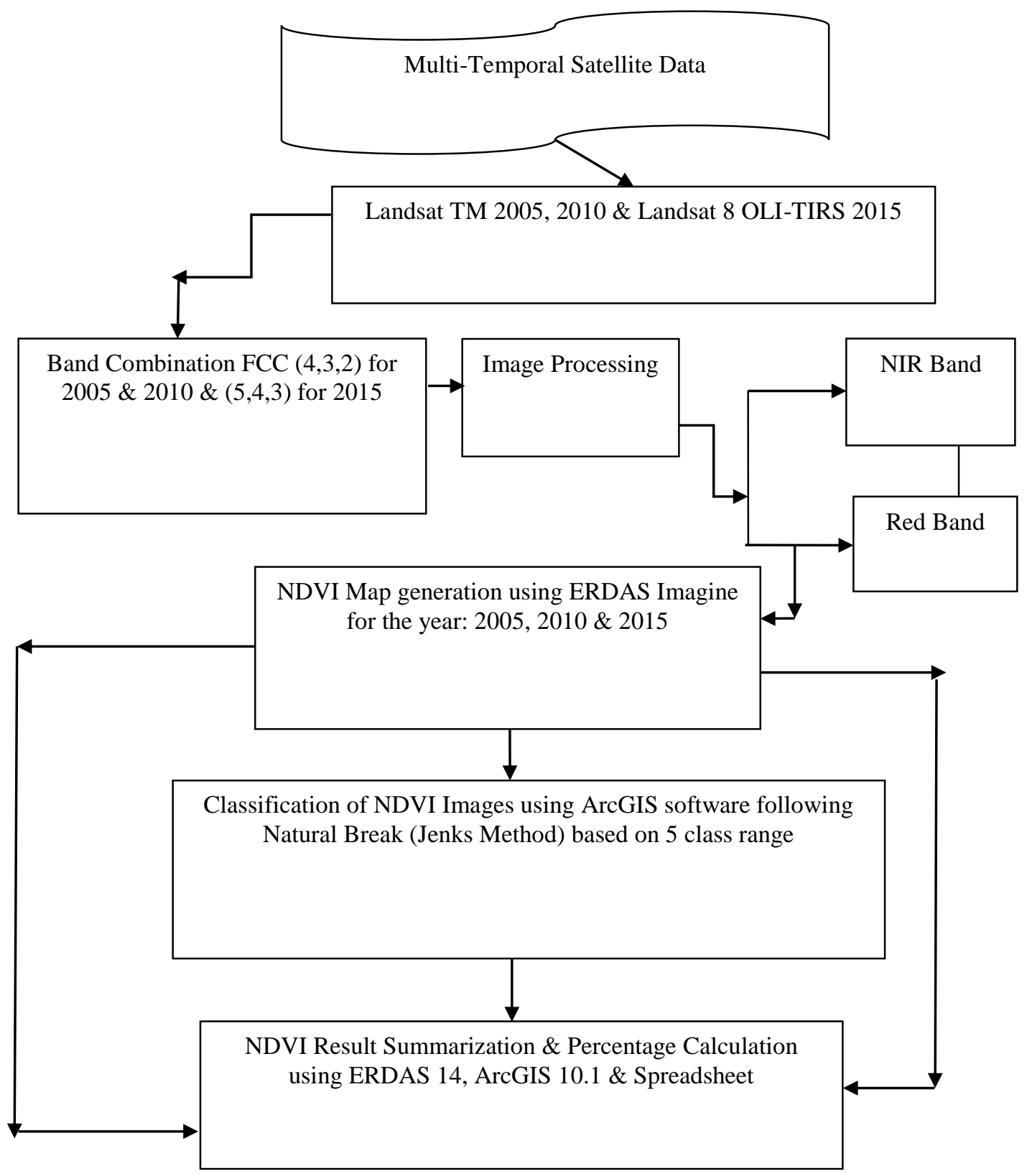

Figure 2. Flow Chart of Methodology for NDVI Classification 


\section{Results and Discussion}

\section{Normalized Difference Vegetation Index (NDVI) calculations using Landsat TM and Landsat 8 OLI-TIRS satellite imageries (2005-2015)}

Vegetation indices have long been used in remote sensing to monitor temporal changes associated with vegetation. NDVI value ranges from -1 to +1 . Rock and bare soil have a very much similar reflectance giving NDVI value close to ' 0 '. Value a little higher than zero in NDVI indicates presence of little vegetation class; while moderate and high values indicate stressed vegetation and healthy vegetation respectively; whereas near zero and negative values indicate non-vegetation like water, snow, built-up areas and barren land.

Using the formula given in methodology section along with the following algorithm, NDVI of CWS calculated:

i. Computation of NDVI values for the entire study areas by conversion of spectral reflectance values into NDVI values.

ii. Conversion of these NDVI values to a scaled channel values by using density-slicing method that measures apparent reflectance to sensor values.

iii. Display of image with NDVI and creation of a legend keeping the threshold values (Figure 3.1(A, B, and C)

The greenness range is divided into discrete classes by slicing the range of NDVI values into five ranges by fixing the thresholds for NDVI classification and the method used is Natural Breaks (Jenks). Similar step was followed for all the three (3) different years' image classification. A cursory examination of pseudo color image of NDVI and classified output of NDVI image reveals that along the water bodies, built up lands yield negative values, their reflectance being more visible rather than near IR wavelengths. This technique is applied for comparison of vegetation cover change from multiple dates of Landsat TM and Landsat $8 \quad$ OLI/TIRS derived NDVI imageries. Figure 3 (A, B and C) shows resultant maps generated from NDVI classification. It shows that high reflectance of vegetation in 2005 image, with an increase in NDVI values but the vegetation reflectance is low in 2015 and rather than moderate reflectance was found in 2010, which shows decreasing scenario. In parallel with these decreasing condition, Forest Plantation is also noticed at ground level investigation period which is the resultant form initiative to regenerate forest in the earlier degraded areas. NDVI image derived statistics for the three different years are shown in Table 2.

The NDVI analysis shows that in 2005, CWS was dominated by medium to high density forest cover $(70 \%$ area in 0.500 0.710 category) mostly concentrated at the core zone of all the beats especially in Chambal, Napura and Puichari beats (Figure 3.1A; Table 3.1). Besides this category, there was also significant amount of forest cover under medium density ( $25 \%$ area in $0.300-0.500$ category) was found everywhere of CWS areas in close attachment with moderate-high density patches and its concentration are prominently visible in the western margin of Jaldi, Chambal, Napura and Puichari beat, whereas this category is mostly dominant in the north, eastern and southern margin of the remaining forest beats i.e., Chunati, Aziznagar and Harbang Forest beats. Lowmoderate density forest areas (value of $0.150-0.300$ ) are found all over CWS areas with dispersed condition highlighted with pink color (3.72\% area) (Figure 3A). 
Islam, K. et al., / IJEGEO 3 (2), 45-55 (2016)

Table 2: NDVI derived change statistics of CWS Areas during 2005-2015

\begin{tabular}{|c|c|c|c|c|c|c|c|c|c|}
\hline $\begin{array}{l}\text { NDVI } \\
\text { value } \\
\text { based } \\
\text { category }\end{array}$ & $\begin{array}{l}\text { NDVI } \\
\text { value } \\
2005\end{array}$ & $\begin{array}{l}\text { Area } \\
(\mathrm{Ha})\end{array}$ & $(\%)$ & $\begin{array}{l}\text { NDVI value } \\
2010\end{array}$ & $\begin{array}{l}\text { Area } \\
(\mathrm{Ha})\end{array}$ & $(\%)$ & $\begin{array}{l}\text { NDVI } \\
\text { value } \\
2015\end{array}$ & Area (Ha) & $(\%)$ \\
\hline WB \& BL & $-0.2-0.0$ & 4.05 & $\begin{array}{l}0.0 \\
3\end{array}$ & $\begin{array}{l}-0.19-(-) \\
0.0001\end{array}$ & 18.54 & $\begin{array}{l}0.1 \\
7\end{array}$ & 0 & 55.66 & 0.51 \\
\hline LD & $0.0-0.15$ & 47.6 & $\begin{array}{l}0.4 \\
4\end{array}$ & $-0.001-0.15$ & 584.28 & 5.4 & $0-0.15$ & 878.74 & 8.11 \\
\hline L-MD & $0.15-0.3$ & 402.12 & $\begin{array}{l}3.7 \\
2\end{array}$ & $0.15-0.3$ & 4655.07 & $\begin{array}{l}43 . \\
01\end{array}$ & $0.15-0.3$ & 9280.73 & 85.76 \\
\hline MD & $0.3-0.5$ & 2760.25 & $\begin{array}{l}25 . \\
51\end{array}$ & $0.3-0.5$ & 5555.16 & $\begin{array}{l}51 . \\
33\end{array}$ & $0.3-0.4$ & 607.64 & 5.62 \\
\hline M-HD & $0.5-0.71$ & 7608.2 & $\begin{array}{l}70 . \\
3\end{array}$ & $0.5-0.562$ & 9.72 & $\begin{array}{l}0.0 \\
9\end{array}$ & NA & NA & NA \\
\hline Total & \multicolumn{3}{|c|}{10822.77} & & \multicolumn{3}{|l|}{10822.77} & 10822.77 & \\
\hline
\end{tabular}

(Note that: $W B \& B L=$ Water bodies \& barren land, $L D=$ Low Density, $L-M D=$ Low-Moderate Density, $M D=$ Moderate Density, $M-H D=$ Moderate-High Density, $N A=$ Not Available)

Density of forest cover showed degrading trend. In 2005, moderate-high density forest was found dominating having an area of 7608.2 hectares $(70.30 \%$ of overall area) but this was found totally absent in 2015 (Table 2. Figure 3A). The year 2010, showed a threatening situation where only 9.72 hectares of moderate-high density vegetation cover was found and most of the forest was found under moderate density ( $51 \%$ area in $0.300-0.500$ category) and low-moderate density (43\% area in 0.150 0.300 category) covers (Table 2; Figure 3B) . Following the trend of losing scenario of moderate-high density vegetation, lowermoderate density vegetation cover dominates the CWS in 2015 (86\% area in $0.150-0.300$ category) (Table 2; Figure 3C). The degradation of moderate-high density vegetation cover is a clear indicator of quantitative and qualitative deterioration of land cover in CWS. Only 47.6 hectares lower density vegetation cover was found in 2005, but this class increased in 2015 with an area of 878.74 hectares. The CWS thus showing a pattern of losing moderate-high quality vegetation cover which if not recovered in near future will bear catastrophic situation. The continuously degrading vegetation cover scenario is shown in Figure 4 for better understanding. 


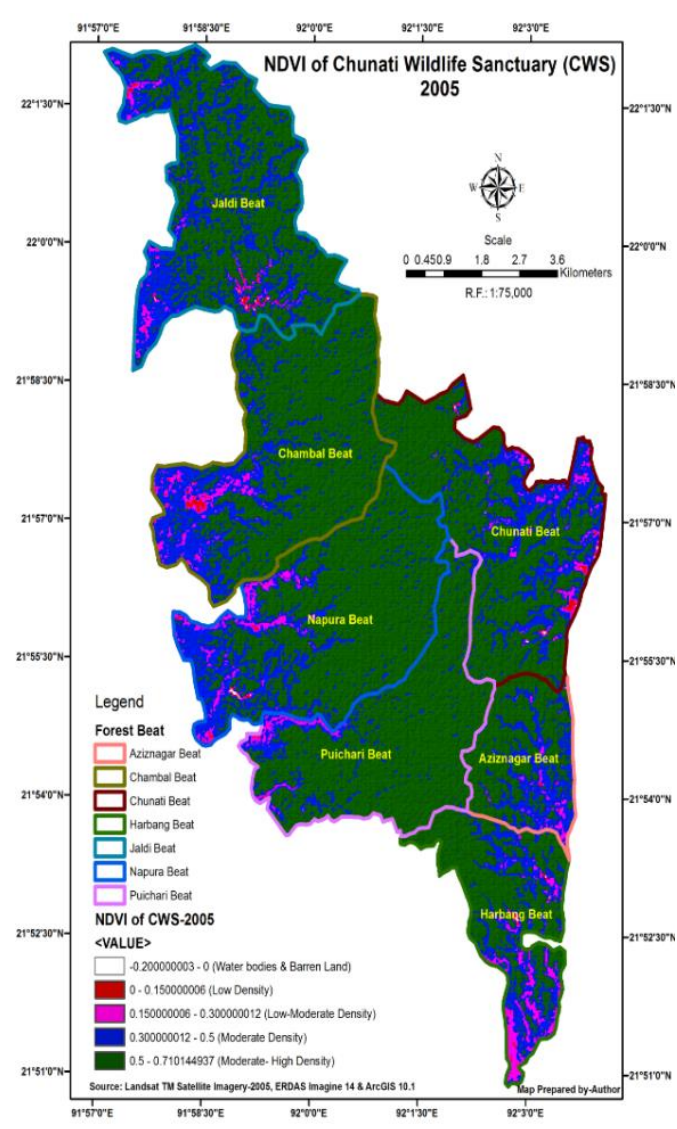

Figure 3A NDVI map of CWS -2005

CWS areas faced severe hill forest degradation due to illegal encroachment and different anthropogenic activities. Large scale timber extraction and massive dependencies of the local people on forest products at regular interval in all seasons had put pressure on forest resources in CWS areas which were clearly identified at this stage. Very high density forest was not observed in the year 2005. The value of ((-) $0.200-0.000)$ indicate water bodies and barren areas which was found in very negligible amount in CWS areas.

Due to illegal encroachment, forest clearance and high dependence of local people on CWS areas, the forest densification was reduced further in 2010 . The derived NDVI values of 2010 sharply indicate decreasing scenarios of forest cover in comparison to 2005. The highest NDVI value of the year 2010 ends with 0.500 0.562 value representing as moderate-high forest density whereas it was higher $(0.500$ 0.710 ) in 2005 (Figure 3B)

After 2005, the satellite derived data gave us a better clue of the forest destruction of CWS areas which shows negative attitude towards forest conservation and it's only happened due to different anthropogenic activities with support of the local influential people, where forest dependency was highly observed by getting this interpretation result. Due to low forest coverage water bodies and barren areas are also in shrinking condition rather than its earlier scenarios. Value ranges 0.299-0.500 (moderate density) and 0.1500.299 (low-moderate density) shows more dominant category ( $2^{\text {nd }}$ highest share and $3^{\text {rd }}$ highest share respectively) which are found all over CWS areas along with moderate density areas (Table 2; Figure $3 \mathrm{~B})$. The vacant land and massive water bodies indicate no vegetation category which is represented by negative NDVI values in the year 2005 and 2010 . On the other hand, due to dry season image of 26 March, 2015 have no minus value representing dry up condition of water bodies which was also noticed during field investigation.

The data of NDVI in 2015 starts with 0.000 which is categorized as barren land and value $(0.000-0.150)$ indicate low density forest which are mainly found in concentrated way in Chambal, Napura, Puichari, and north-south alignment of the Jaldi beat highlighted as brick red color respectively (Table $2 \&$ Figure 3C).The CWS areas had faced massive human intervention which started after the year 1991 where severe cyclonic storm was damaged in the surrounding regions of it, so people had no choice at that time to move anywhere. They found shelter in the nearby safer place which is inside the CWS and its close proximity areas. People were very much dependent on the Chunati forest resources for their livelihood because it was easily accessible from their shelter areas. 


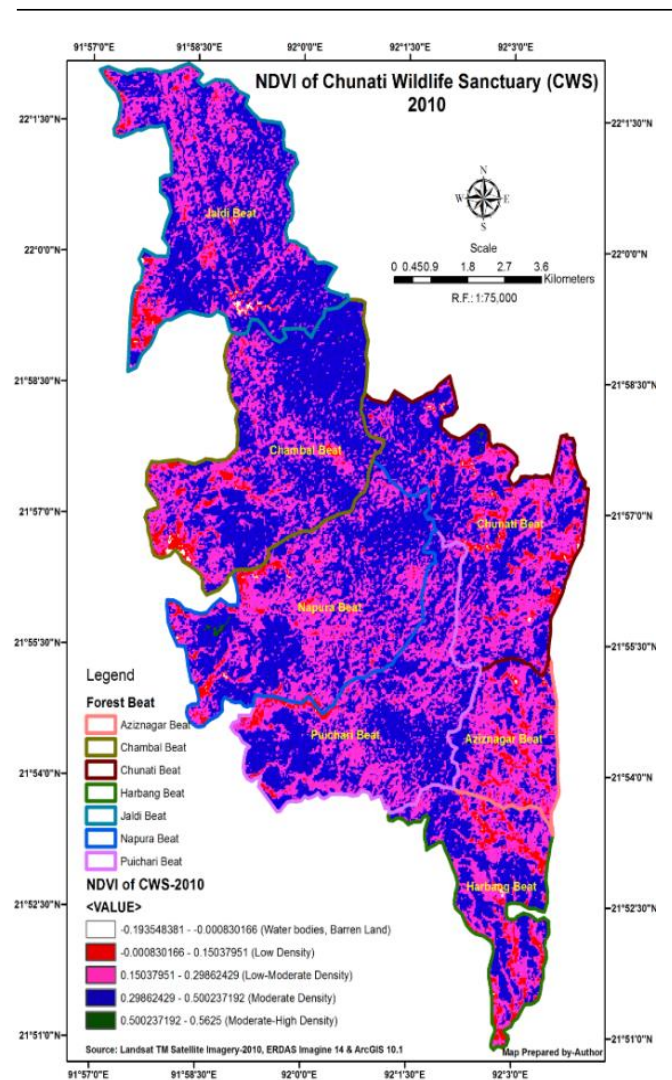

Figure: 3B: NDVI map of CWS-2010

Due to their dependencies, seven forest beats are extensively damaged at higher rate for different purposes i.e., establishment of settlements, extraction of timber and other resources. Recent survey shows that due to social awareness, alternative activities provided by the different NGO's and people's willingness to change their profession rather than forest destruction and plantation in the degraded areas is improving the scenarios of the CWS areas but the current scenarios till 26 March 2015, the NDVI result shows the situation is not improving. In 2015 image, moderate to high density and high density forest classes were found absent in the CWS areas. The value of 0.150-0.299 represents low-moderate density forest coverage of CWS areas which are found in every single forest beat with high concentration highlighted with pink color and moderate density (NDVI value 0.299-0.404) represents with blue color (Figure 3C).

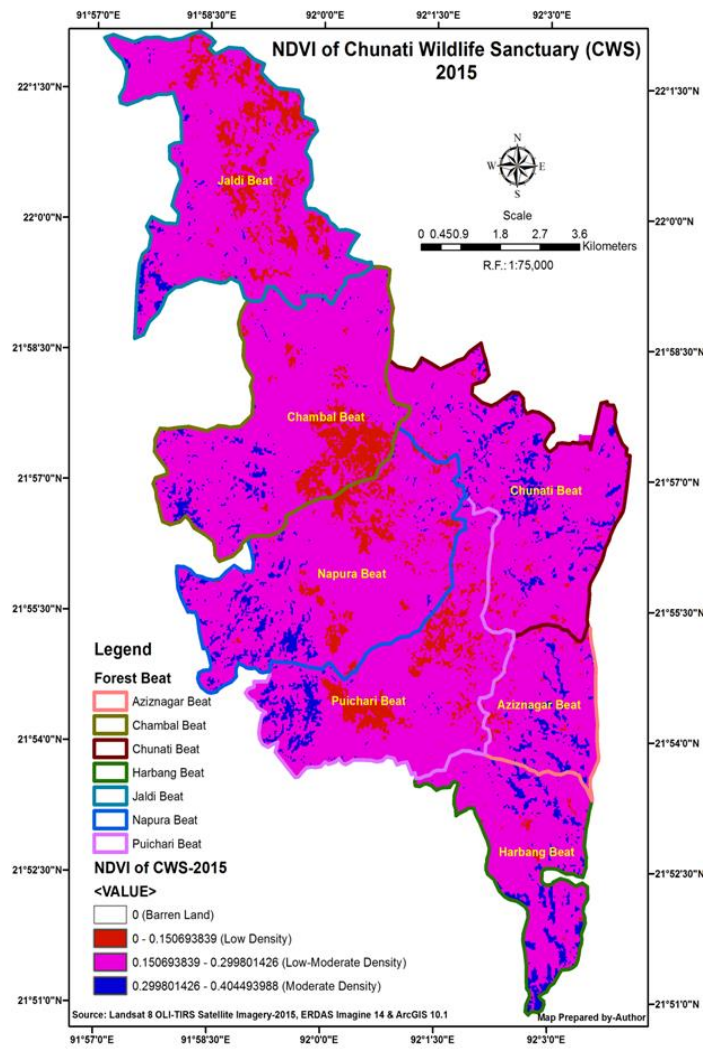

Figure 3C: NDVI map of CWS-2015

\section{Conclusion}

Remote sensing \& GIS along with satellite derived images are some powerful tools that are widely used in natural resource management sectors. Using these tools along human intelligence is thus a better option to take management decision in natural resource management. In this study satellite imageries of 2005, 2010, and 2015 of CWS were used to detect land cover change and was done using NDVI. The results derived from the experiment is highly satisfactory. Although there are some other tools that are also used in land use/land cover change assessment, but most of them are costly. There lies the scope of this research as very simple technique was used and the cost needed for this kind of research was minimal. It is hoped that this research along with generating new knowledge in the field of land use/cover management, will also help in local, regional, and national scale land use policy decision. 


\section{Temporal Change in Land Cover}

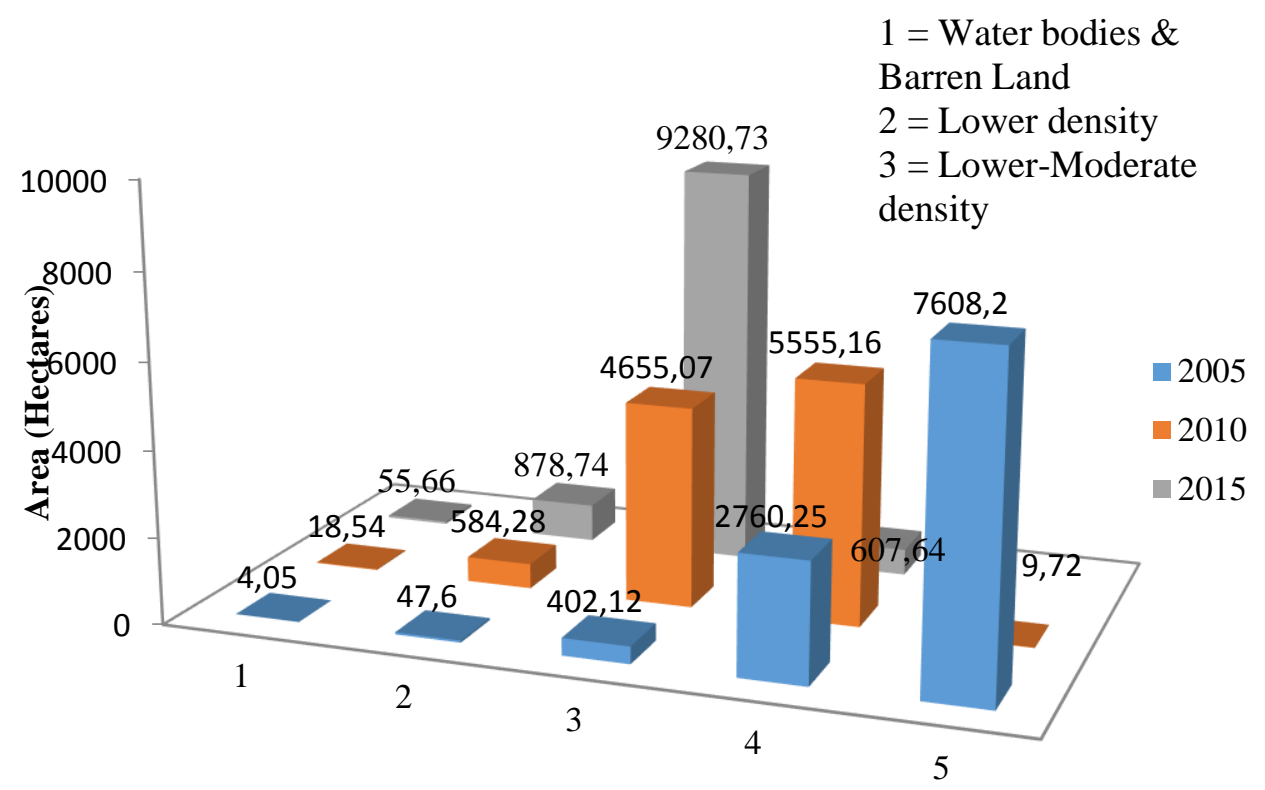

NDVI Value Based Category

Figure 4: Temporal Change of Land Cover in CWS

Results of this research showed that, natural forest cover of CWS was following a decreasing trend which may be considered as a threat. Although there was an increase in land area for forested category from (2005-2015), field observation along with NDVI derived classified maps of the different temporal scale, it was clear that the CWS area was losing forest cover both quantitatively and qualitatively. Thus deep forest patches were only present in some areas in a very scattered mode. From this study, it is found that moderate-high density forest was only present in 2005 (NDVI value 0.71). After that due to anthropogenic disturbances or other related reasons, this area started to lose the forest cover. Thus, the highest NDVI value found was only 0.5 for 2010 and 0.4 for 2015 respectively. This clearly shows the conversion scenarios of moderate-deep forest cover to low or low - moderate forest cover from 2005-2015 time period in CWS.

\section{References}

Agarwal, C., Green, G. M., Grove, J. M., Evans, T. P., \& Schweik, C. M. (2001). A Review and Assessment of Land-Use Change Models Dynamics of Space, Time, and Human Choice. CIPEC Collaborative Report Series No. 1, Center for the Study of Institutions Population, and Environmental Change Indiana University.

Aspinall, R. (2004). Modelling land use change with generalized linear models - A multimodel analysis of change between 1860 and 2000 in Gallatin Valley, Montana. Journal of Environmental Management, 72, 91-103.

Campbell, J. B., Introduction to Remote Sensing, The Guilford Press, New York, 1987.

Chuvieco, E., "El factor temporal enteledeteccio'n: evolutio'n fenomenolo'gica y ana'lisis de cambio, Revista de Teledeteccio'n, 10. 1 -9. 1998. 
Coffey, R., 2013. The difference between "land use" and "land cover" [www Document]. URL The difference between "land use" and "land cover"

Ellis, E. (2013). Land-use and land-cover change. The Encyclopedia of Earth.

FAO. (1995). Planning for sustainable use of land resources Towards a new approach. FAO Land and Water Bulletin 2, Rome.

Geist, H. J. (2005). The Land-Use And Cover Change (Lulc) Project. Land Use, Land Cover And Soll Sciences, I. Retrieved from http://www.eolss.net/samplechapters/c19/E1-05.pdf

Hoffer, R. M., Biological and Physical considerations in Applying Computeraided analysis techniques to Remote sensor data, In Remote Sensing: The quantitative approach, edited by $\mathrm{P}$. H. Swamand S.M. Davis Mc Graw-Hill.; U.S.A., 1978.

Lambin, E. F. (1997). Modelling and monitoring land-cover change processes in tropical regions. Progress in Physical Geography, 21(3), 375-393.

Lambin, E. F., Turner, B. L., Geist, H. J., Agbola, S. B., Angelsen, A., Folke, C., Veldkamp, T. A. (2001). The causes of land-use and land-cover change : moving beyond the myths. Global Environmental Change, 11, 261-269. Retrieved from www.elsevier.com/locate/gloenvcha.

Lillesand, T. M., and Keifer, R. W., Remote Sensing and Image Interpretation; John Wiley and Sons, New York, 1979, 1994 and 2000.

López, E., Bocco, G., Mendoza, M., \& Duhau, E. (2001). Predicting land-cover and land-use change in the urban fringe. Landscape and Urban Planning, 55(4), 271-285.
NSP. (2004). Site-Level Field Appraisal for Protected Area Co-Management: Chunati Wildlife Sanctuary. International Resources Group (IRG).

Singh, A., "Review Article: Digital Change Detection Techniques using Remotely Sensed Data," International Journal of Remote Sensing, 10. 989-1003. 1989.

Tovar, C. L. Meneses., "NDVI as indicator of Degradation," Unasylva, 62. 238. 2012.

Veldkamp, A, and Lambin, E. . (2001). Predicting land-use change. Agriculture, Ecosystems \& Environment, 85, 1-6.

Veldkamp, A., L, F., 1997. Exploring land use scenarios, an alternative approach based on actual land use. Agric. Syst. 1-17.

Vescovi, F. D., Park, S. J., and Vlek, P. L. (2002, September). Detection of humaninduced land cover changes in a savannah landscape in Ghana: I. Change detection and quantification. In 2nd Workshop of the EARSeL Special Interest Group on Remote Sensing for Developing Countries. Bonn, Germany.

Zeng, Y.N., Wu, G.P., Zhan, F.B., Zhang, H. H. (2008). Modeling spatial land use pattern using autologistic regression. The International Archives of the Photogrammetry, Remote Sensing and Spatial Information Sciences, XXXVII, 115-118. 